\title{
Pengaruh Suhu dan Lama Penyimpanan terhadap Kadar Nitrit pada Rebusan Bayam Hijau
}

\author{
Hendra Budi Sungkawa ${ }^{1}$, Sugito $^{2}$ \\ Jurusan Analis Kesehatan, Politeknik Kesehatan Kemenkes Pontianak, Indonesia \\ Email: hendrabudis.budis@gmail.com
}

\begin{abstract}
Effect of Temperature and Duration of Storage on Nitrite Levels on Green Spinach Decoction. Spinach is a highly nutritious leaf vegetable that is beneficial to the body, including one of the plants recommended fields to support the Family Nutrition Improvement Business (FNIB). Spinach contains nitrate $\left(\mathrm{NO}_{3}^{-}\right)$which is reduced by air will become nitrite $\left(\mathrm{NO}_{2}\right)^{-}$. Consuming spinach should not be more than 5 hours after cooking, because if consumed in a situation that has been left it can cause poisoning in the body. This study was a quasiexperiment with Griess II examination method with Perkin Elmer's Lambda 25 UV-Vis Spectrophotometer which aims to determine the effect of temperature and storage time on nitrite levels in green spinach stew. The results of data processing showed nitrite levels in green spinach stew stored for 3 hours at $0.017 \mathrm{mg} / \mathrm{L}$ and $0.038 \mathrm{mg} / \mathrm{kg}$, for 6 hours at $0.076 \mathrm{mg} / \mathrm{L}$ and $0.015 \mathrm{mg} / \mathrm{kg}$ and for 9 hours at $0.428 \mathrm{mg} / \mathrm{L}$ and $0.005 \mathrm{mg} / \mathrm{kg}$. The level of storage in the room, the lowest value is $0.009 \mathrm{mg} / \mathrm{L}$ while the highest value is $0.915 \mathrm{mg} / \mathrm{L}$. Whereas in the refrigerator storage the lowest value is $0.003 \mathrm{mg} / \mathrm{L}$ and the highest level is $0.048 \mathrm{mg} / \mathrm{L}$. The conclusion in this study is that there are differences in nitrite levels in boiled green spinach which are stored for 3 hours, 6 hours, and 9 hours, and there is an effect of storage temperature on nitrite levels with very strong relationship strength.
\end{abstract}

Keywords: Green spinach, Nitrite level, Storage, Temperature, Time

\begin{abstract}
Abstrak: Pengaruh Suhu dan Lama Penyimpanan terhadap Kadar Nitrit pada Rebusan Bayam Hijau. Bayam merupakan bahan sayuran daun bergizi tinggi yang bermanfaat bagi tubuh sehingga termasuk salah satu tanaman perkarangan yang dianjurkan dalam rangka menunjang Usaha Perbaikan Gizi Keluarga (UPGK). Bayam mengandung zat nitrat $\left(\mathrm{NO}_{3}^{-}\right.$) yang jika tereduksi dengan udara maka akan menjadi nitrit $\left(\mathrm{NO}_{2}-\right)$. Mengkonsumsi bayam tidak boleh lebih dari 5 jam setelah dimasak, karena jika dikonsumsi dalam keadaan yang sudah didiamkan dapat menyebabkan keracunan pada tubuh. Penelitian ini merupakan eksperimen semu dengan metode pemeriksaan Griess II dengan alat Spektrofotometer UV-Vis Perkin Elmer's Lambda 25 yang bertujuan untuk mengetahui pengaruh suhu dan waktu penyimpanan terhadap kadar nitrit pada rebusan bayam hijau. Hasil pengolahan data menunjukkan kadar nitrit pada rebusan bayam hijau yang disimpan selama 3 jam sebesar $0,017 \mathrm{mg} / \mathrm{L}$ dan $0,038 \mathrm{mg} / \mathrm{kg}$, selama 6 jam sebesar $0,076 \mathrm{mg} / \mathrm{L}$ dan $0,015 \mathrm{mg} / \mathrm{kg}$ serta selama 9 jam sebesar $0,428 \mathrm{mg} / \mathrm{L}$ dan $0,005 \mathrm{mg} / \mathrm{kg}$. Kadar penyimpanan didalam ruangan nilai terendah yaitu $0,009 \mathrm{mg} / \mathrm{L}$ sedangkan nilai tertingginya yaitu $0,915 \mathrm{mg} / \mathrm{L}$. Sedangkan pada penyimpanan didalam kulkas nilai terendahnya yaitu $0,003 \mathrm{mg} / \mathrm{L}$ dan nilai tertingginya adalah $0,048 \mathrm{mg} / \mathrm{L}$. Kesimpulan dalam penelitian ini yaitu ada perbedaan kadar nitrit pada rebusan bayam hijau yang disimpan selama 3 jam, 6 jam, dan 9 jam, dan ada pengaruh suhu penyimpanan terhadap kadar nitrit dengan kekuatan hubungan sangat kuat.
\end{abstract}

Kata kunci: Bayam hijau, Kadar nitrit, Penyimpanan, Suhu, Waktu

\section{PENDAHULUAN}

Mengkonsumsi makanan tidak hanya berkaitan dengan proporsi makanan, sebaiknya makanan yang dikonsumsi memenuhi kebutuhan tubuh akan karbohidrat, protein, vitamin dan zat lainnya untuk pertumbuhan dan kesehatan tubuh manusia. Jenis makanan yang kurang menjadi perhatian salah satunya adalah sayuran (Nengsih, 2012).

Sayuran komersil yang mudah diperoleh disetiap pasar tradisional maupun modern salah satunya yaitu bayam. Harganya relatif murah sehingga dapat terjangkau oleh semua lapisan masyarakat (Manalu, 2011).

Keunggulan nilai nutrisi bayam yaitu kandungan vitamin A (beta-karoten), vitamin C, 
riboflavin dan asam amino thiamine dan niacin. Bayam mengandung kalsium dan zat besi serta kaya akan mineral lain seperti seng (zink), magnesium, fosfor, dan kalium (Hadisoeganda, 1996). Di dalam daun bayam terdapat cukup banyak kandungan protein, mineral, kalsium, zat besi, dan vitamin yang dibutuhkan oleh tubuh manusia (Rahayu, Asgar, Hidayat, \& Djuariah, 2013). Cara pemanfaatan bayam sebagai bahan perawatan kesehatan, selain melalui masakan, bisa dilakukan dengan meminum air sari bayam secara teratur yang diperoleh dengan merebus beberapa helai daun, tangkai atau akar bayam. Walaupun bayam kaya akan zat gizi yang bermanfaat bagi tubuh, bayam juga mengandung zat nitrat $\left(\mathrm{NO}_{3}{ }^{-}\right)$, kalau tereduksi dengan udara, maka akan menjadi nitrit $\left(\mathrm{NO}_{2}^{-}\right)$(Fitriani, Nurlailah, \& Rakhmina, 2016). Menurut Jhon S Wishnok, bayam segar yang baru dicabut dari persemaiannya telah mengandung senyawa nitrit kira-kira sebanyak 5mg per kg (Manalu, 2011).

Mengkonsumsi bayam tidak boleh lebih dari 5 jam setelah dimasak, karena jika dikonsumsi dalam keadaan yang sudah didiamkan dapat menyebabkan keracunan pada tubuh karena kandungan nitrat yang tereduksi (Jamaluddin, 2013). Efek toksik (meracuni tubuh) yang ditimbulkan oleh nitrit bermula dari reaksi oksidasi nitrit dengan zat besi dalam sel darah merah tepatnya di hemoglobin. Ikatan nitrit dengan hemoglobin disebut methemoglobin yang mengakibatkan hemoglobin tidak mampu mengikat oksigen. Jika jumlah methemoglobin mencapai lebih dari $15 \%$ dari total hemoglobin, maka akan terjadi sianosis yang artinya keadaan dimana seluruh jaringan tubuh manusia kekurangan oksigen (Jamaluddin, 2013).

Menurut Joint FAO/WHO Expert Committee on Food Additives (JECFA) bahwa nilai asupan harian yang aman atau Acceptable Daily Intake (ADI) untuk nitrit adalah 0,07 $\mathrm{mg} / \mathrm{kg}$ berat badan (Ismail et al., 2011). Penelitian lain menunjukkan kandungan nitrit pada rebusan sayur bayam hijau dengan metode spektrofotometri dengan variasi waktu $0,1,2,3$, 4 , dan 5 jam yaitu 4,$159 ; 5,319 ; 7,239 ; 8,719 ; 10$, 149; dan 11,559mg/kg (Manalu, 2011).

Hasil uji pendahuluan yang dilakukan oleh peneliti terhadap sampel rebusan bayam hijau sebelum disimpan didapatkan nilai kandungan nitrit dengan rata-rata yaitu $0,998 \mathrm{mg} / \mathrm{kg}$.

\section{METODE}

Penelitian ini menggunakan Quasi experimental dengan teknik Purposive Sampling.
Kriteria sampel yaitu bayam hijau bagian batang dan daunnya yang masih segar tidak layu dan tidak busuk (Sugiyono, 2016). Besar sampel yaitu 27 sampel didapatkan dengan membuat tiga perlakuan rebusan bayam hijau yang disimpan selama 3 jam, 6 jam, dan 9 jam dengan sembilan kali replikasi untuk masing-masing perlakuan (Sujarweni, 2015).

Penelitian ini dilakukan di Laboratorium Aneka Komoditi Balai Riset dan Standarisasi Industri dan Perdagangan Pontianak. Pengumpulan data dilakukan oleh peneliti dengan melakukan pemeriksaan nitrit metode Griess II dengan alat Spektrofotometer UV-Vis Perkin Elmer's Lambda 25. Prosedur kerja meliputi tahapan persiapan alat dan bahan, penanganan sampel, preparasi sampel, analisis kualitatif, dan analisis kuantitatif. Persiapan alat berupa neraca analitik, labu takar $100 \mathrm{~mL}$, pipet ukur $10 \mathrm{~mL}$, gelas ukur $25 \mathrm{~mL}$, labu erlenmeyer $300 \mathrm{~mL}$, dan gelas piala $50 \mathrm{~mL}$. Persiapan bahan berupa bayam, larutan asam sulfanilat, larutan NED, dan larutan baku nitrit. Bayam ditimbang 100gram direbus dengan 1 liter aquades mendidih selama 5 menit kemudian dibedakan variasi waktu penyimpanan setelah perebusan, yaitu selama 3 jam, 6 jam, dan 9 jam. Preparasi sampel dilakukan dengan menggerus 25gram sampel yang dicampur dengan $200 \mathrm{~mL}$ air panas sulingan kemudian disaring dengan kertas saring Whatman No 1. dan filtratnya digunakan untuk penentuan kadar nitrit (Ismail et al., 2011). Analisis kualitatif dilakukan untuk mengetahui adanya kandungan nitrit dengan menambahkan $1 \mathrm{~mL}$ larutan asam sulfanilat, $1 \mathrm{~mL} \alpha$ diphenyl amin dan $1 \mathrm{~mL}$ NED kedalam sampel kemudian diamati perubahan warna larutan menjadi merah muda. Analisis kuantitatif dilakukan dengan cara $20 \mathrm{~mL}$ dari setiap filtrat dipipet ke dalam labu takar ditambah $0,5 \mathrm{~mL}$ pereaksi sulfanilamide, dihomogenkan dan diinkubasi selama 2-8 menit kemudian ditambahkan $0,5 \mathrm{~mL}$ pereaksi NED yang dihomogenkan dan diinkubasi selama 2 jam sampai terbentuk warna merah muda yang selanjutnya dibaca absorbansinya pada panjang gelombang $543 \mathrm{~nm}$. Data yang diperoleh dalam penelitian ini kemudian dikelompokkan dalam bentuk tabel dan narasi. Kemudian dilakukan analisis dengan uji Anava-One way dan uji regresi.

Penelitian ini telah mendapatkan persetujuan komisi etik (ecthics committee approval) dari Komisi Etik Politeknik Kesehatan Tanjung Karang dengan No.014/KEPKPK.PKP/VI/2018. 


\section{HASIL}

Hasil perlakuan rebusan bayam hijau menunjukkan rata-rata kadar nitrit yang disimpan selama 3 jam adalah $0,017 \mathrm{mg} / \mathrm{L}$ dan $0,038 \mathrm{mg} / \mathrm{kg}$, yang disimpan selama $6 \mathrm{jam}$ adalah $0,076 \mathrm{mg} / \mathrm{L}$ dan $0,015 \mathrm{mg} / \mathrm{kg}$ serta yang disimpan selama 9 jam adalah $0,428 \mathrm{mg} / \mathrm{L}$ dan $0,005 \mathrm{mg} / \mathrm{kg}$. Dengan kadar terendah pada kelompok Ruangan adalah $0,009 \mathrm{mg} / \mathrm{L}$ dan tertingginya adalah $0,915 \mathrm{mg} / \mathrm{L}$, sedangkan pada kelompok Kulkas nilai terendahnya adalah $0,003 \mathrm{mg} / \mathrm{L}$ dan kadar tertingginya adalah $0,048 \mathrm{mg} / \mathrm{L}$.

Tabel 1. Hasil Uji Kadar Nitrit pada Rebusan Bayam Hijau yang Disimpan Selama 3 Jam, 6 Jam dan 9 Jam

\begin{tabular}{lrccrcc}
\hline \multirow{2}{*}{ Waktu penyimpanan } & \multicolumn{3}{c}{ Ruangan } & \multicolumn{3}{c}{ Kulkas } \\
\cline { 2 - 7 } & Rerata & Min & Max & Rerata & Min & Max \\
\hline 3 Jam & 0.017 & 0.009 & 0.038 & 0.038 & 0.028 & 0.048 \\
6 Jam & 0.076 & 0.034 & 0.207 & 0.015 & 0.006 & 0.011 \\
9 Jam & 0.428 & 0.118 & 0.915 & 0.005 & 0.003 & 0.006 \\
\hline
\end{tabular}

Hasil uji statistik menggunakan KruskalWallis diperoleh nilai signifikansi $p=0,000$ $(p<0,05)$, yang berarti terdapat perbedaan kadar nitrit pada rebusan bayam hijau yang disimpan selama 3 jam, 6 jam dan 9 jam.

Tabel 2. Hasil Uji Perbedaan Kadar Nitrit Pada Rebusan Bayam Hijau yang Disimpan Selama 3 Jam, 6 Jam dan 9 Jam

\begin{tabular}{lcc}
\hline & Ruangan & Kulkas \\
\hline Nilai Chi Square & 18.891 & 23.472 \\
Nilai Signifikasi & 0.000 & 0.000 \\
\hline
\end{tabular}

Hasil uji statistik menggunakan Uji Korelasi diperoleh nilai signifikansi $p=0,000$ $(p<0,05)$, dengan nilai r 0.636 pada kelompok Ruangan, yang artinya memiliki hubungan positif dan nilai $\mathrm{r}-0.870$ pada kelompok Kulkas yang berarti memiliki hubungan negatif.

\section{Tabel 3. Hasil Uji Hubungan Kadar Nitrit pada Rebusan Bayam Hijau yang Disimpan Selama 3 Jam, 6 Jam dan 9 Jam dengan Temperatur Simpan

\begin{tabular}{lcc}
\hline & Ruangan & Kulkas \\
\hline Nilai r & 0.636 & -0.870 \\
Nilai Signifikasi & 0.000 & 0.000 \\
\hline
\end{tabular}

Peningkatan kadar nitrit pada kelompok Ruangan tersebut dapat terjadi dikarenakan adanya perubahan zat nitrat yang ada di dalam bayam menjadi nitrit. Ini sesuai dengan hasil uji korelasi yang memiliki nilai $\mathrm{r}$ 0.636, dimana hubungannya positif. Hal ini menunjukkan bahwa semakin lama waktu penyimpanan, maka semakin tinggi perubahan nitrat menjadi nitrit.

Hasil uji statistik menggunakan Uji Regresi diperoleh nilai signifikansi $p=0,000$ $(p<0,05)$, dengan nilai $\mathrm{R}$ Square 0.404 pada kelompok Ruangan, yang artinya $40.4 \%$ perubahan terjadi karena pengaruh temperatur dan nilai $R$ Square 0.757 pada kelompok kulkas yang berarti $75.7 \%$ perubahan terjadi karena pengaruh temperatur.

Tabel 4. Pengaruh Temperatur Penyimpanan dengan Variasi Waktu Penyimpanan

\begin{tabular}{lrr}
\hline & Ruangan & \multicolumn{1}{c}{ Kulkas } \\
\hline Nilai R & 0.404 & 0.757 \\
Square & & \\
Nilai & 0.000 & 0.000 \\
Signifikasi & & \\
\hline
\end{tabular}

Penurunan kadar nitrit pada kelompok Kulkas tersebut dapat terjadi dikarenakan terhambatnya aktivitas enzim perubah nitrit. Ini sesuai dengan hasil uji Korelasi yang memiliki nilai $\mathrm{r}-0.870$, dimana hubungannya negatif. Hal ini menunjukkan bahwa semakin lama waktu penyimpanan, maka semakin rendah kadar nitritnya.

\section{PEMBAHASAN}

Nitrat merupakan senyawa nitrogen yang dapat terdegradasi menjadi nitrit. Nitrit merupakan senyawa yang dapat berinteraksi dengan senyawa lain pada proses pencernaan sehingga membentuk nitrosamine. Nitrosamine yaitu zat beracun yang bersifat karsinogenik (Romsiah \& Meidalena, 2017).

Perubahan zat nitrat menjadi nitrit ini berawal dari bayam yang dimasak sehingga selsel tanaman mati dan timbul zat hasil urai yaitu amoniak. Sebagian amoniak terlepas di udara dan sebagian lain digunakan oleh genus bakteri untuk membentuk nitrit. Oksidasi amoniak menjadi nitrit berlangsung dalam lingkungan yang aerob yang disebut dengan proses nitrifikasi. Perubahan ini dilakukan oleh enzim nitrat reduktase yang berasal dari bakteri yang ada di udara saat bayam didiamkan. Enzim nitrat reduktase ini berperan 
dalam proses nitrifikasi tergantung dari konsentrasi substrat dan intensitas cahaya.

Komponen nitrat maupun nitrit dapat menjadi komponen yang tidak stabil pada suhu tertentu (Kasmira, Lahming, \& Fadillah, 2018). Dalam penelitian ini, faktor suhu memberikan pengaruh terhadap perubahan nitrat menjadi nitrit. Kadar nitrit mengalami peningkatan terutama pada suhu diatas $0^{0} \mathrm{C}$ karena perubahan nitrat menjadi nitrit oleh enzim nitrat reduktase hadir dalam bakteri.

Nitrit adalah ion-ion anorganik alami, yang merupakan bagian dari siklus nitrogen. Nitrit dapat terbentuk dari aktifitas mikroba di tanah atau air yang merubah nitrat menjadi nitrit (Manalu, 2011). Sebagian besar nitrogen yang terdapat dalam organisme hidup berasal dari penambatan (reduksi) oleh mikroorganisme prokariot. Sebagian diantaranya terdapat di akar tumbuhan atau dari pupuk hasil penambatan secara industri. Pupuk merupakan salah satu sumber penting nitrogen pada tumbuhan (Armiadi, 2007). Pada penelitian ini faktor pupuk tidak dikendalikan.

Menurut John S Wishnok, bayam segar yang baru dicabut dari persemaiannya telah mengandung senyawa nitrit kira-kira sebanyak 5 $\mathrm{mg} / \mathrm{kg}$. Bayam juga mengandung senyawa nitrat sehingga dengan waktu penyimpanan yang lama akan merubah nitrat menjadi nitrit (Manalu, 2011).

Nitrit merupakan zat toksik yang terdapat di dalam bayam. Oleh karena itu, tidak baik mengkonsumsi bayam yang masa penyimpanannya terlalu lama (Suwardi, 2011).

\section{DAFTAR PUSTAKA}

Armiadi. (2007). Efektivitas Penambatan Nitrogen Udara Oleh Bakteri Rhizobium Dengan Penambahan Unsur Hara Molibdenum Pada Tanaman Leguminosa Herba. (Tesis, Sekolah Pasca Sarjana, Institut Pertanian Bogor). Bogor.

Fitriani, H., Nurlailah, N., \& Rakhmina, D. (2016). Kandungan Asam Oksalat Sayur Bayam. Medical Laboratory Technology Journal, 2(2). https://doi.org/10.31964/mltj.v2i2.95

Hadisoeganda, A. W. W. (1996). Bayam Sayuran Penyangga Petani di Indonesia. Bandung: Balai Penelitian Tanaman Sayuran.

Ismail, A., Prasad, K. N., \& Bao, Y. (2011). Changes in nitrate and nitrite levels of blanched amaranthus during refrigeration storage. Jurnal Sains Kesihatan Malaysia
Semakin lama waktu penyimpanan, semakin tinggi konsentrasi nitrit (Ismail et al., 2011). Efek toksik yang ditimbulkan oleh nitrit bermula dari reaksi oksidasi nitrit dengan zat besi dalam sel darah merah tepatnya di hemoglobin. Ikatan nitrit dengan hemoglobin disebut dengan methemoglobin. Dalam keadaan methemoglobin ini, hemoglobin tidak lagi dapat menjalankan fungsinya untuk mengikat oksigen. Darah yang mengandung methemoglobin yang tinggi disebut methemoglobinemia. Jika jumlah methemoglobin mencapai lebih dari $15 \%$ dari total hemoglobin, maka akan terjadi sianosis dengan gejala tubuh berwarna biru, sesak nafas, mual, muntah-muntah dan shock. Oleh karena itu, bayam yang sudah dimasak sebaiknya segera dikonsumsi (Nurjanah, Hamidah, \& Anggereini, 2017).

Dari hasil penelitian ini rebusan bayam hijau yang disimpan selama 3 jam, 6 jam dan 9 jam mengalami peningkatan dalam setiap jamnya yaitu kira-kira $0,03 \mathrm{mg} / \mathrm{kg}$, sehingga rebusan bayam yang disimpan selama 3 jam, 6 jam dan 9 jam masih aman dikonsumsi. Menurut FAO, nilai asupan harian nitrit yang aman adalah 0,07 $\mathrm{mg} / \mathrm{kg}$ berat badan (Ismail et al., 2011).

\section{SIMPULAN}

Terdapat perbedaan kadar nitrit pada rebusan bayam hijau yang disimpan selama 3 jam, 6 jam dan 9 jam. Ada pengaruh suhu penyimpanan terhadap kadar nitrit dengan kekuatan hubungan sangat kuat.

(Malaysian Journal of Health Sciences), 9(1).

Jamaluddin. (2013). Perancangan Media Informasi Tentang Cara Pengolahan Bayam, 55-60.

Kasmira, Lahming, \& Fadillah, R. (2018). Analisis Perubahan Komponen Kimia Keripik Bayam Hijau (Amaranthus tricolor L.) Akibat Proses Penggorengan. Jurnal Pendidikan Teknologi Pertanian, 4, 49-55.

Manalu, H. (2011). Analisa Perubahan Kandungan Nitrit (No2-) Dalam Hasil Rebusan Sayur Bayam Hijau Dengan Metode Spektrofotometri. (Tesis, Fakultas Matematika Dan Ilmu Pengetahuan Alam Universitas Sumatera Utara). Medan.

Nengsih, R. F. (2012). Pengaruh Cara dan Suhu Pengolahan Terhadap Kandungan Pada 
Daun Singkong (Manihot utilisima) Tumbuk. (Skripsi, Jurusan Biologi, Universitas Negeri Medan).

Nurjanah, Hamidah, A., \& Anggereini, E. (2017). Pengaruh Perasan Daun Pepaya (Carica Papaya L.) Terhadap Kondisi Hematologi Mencit Jantan (Mus Musculus Linn.) Anemia Melalui Induksi Natrium Nitrit. AIP Conference Proceedings, 3(3), 2-4. https://doi.org/10.1063/1.4981832

Rahayu, S. T., Asgar, A., Hidayat, I. M., \& Djuariah, D. (2013). Evaluasi Kualitas Beberapa Genotipe Bayam (Amaranthus sp) Pada Penanaman Di Jawa Barat. Berita Biologi, 12(2), 153-160.

Romsiah, \& Meidalena, T. (2017). Validasi Metode dan Penetapan Kadar Nitrit (NO2) pada Hasil Rebusan Sayuran Hijau (Kangkung, Brokoli, Seledri) Menggunakan Spektrofotometer UV-Vis. Jurnal Penelitian Sains, 19(1). Retrieved from

http://ejurnal.mipa.unsri.ac.id/index.php/jp s/article/view/6

Sugiyono. (2016). Metode Penelitian Kuantitatif, Kualitatif, dan $R \& D$. Bandung: Alfabeta.

Sujarweni, V. W. (2015). Statistik Untuk Kesehatan. Yogyakarta: Gava Media.

Suwardi. (2011). Analisis Kadar Oksalat Dalam Daun Bayam Yang Sudah Dimasak Dengan Metode Spektrofotometri UV. (Skripsi, Universitas Islam Negeri Sultan Syarif Kasim Riau). Pekanbaru. 